\title{
Effect of Insulin in vitro on the Isolated, Perfused Alloxan-Diabetic Rat Liver
}

\author{
Y. B. Lombardo ${ }^{1}$, W. T. Hron, and L. A. Menahan \\ Departments of Biochemistry and Pharmacology, Medical College of Wisconsin, Milwaukee, Wisconsin, USA
}

Summary. Withdrawal of exogenous insulin and a subsequent fast $(24 \mathrm{~h})$ of alloxan diabetic rats stimulated rates of gluconeogenesis, ureogenesis, ketogenesis, and amino acid release by in situ perfused livers when compared to those from normal, fasted rats. The contribution of liver glycogen to the high rates of gluconeogenesis observed with the diabetic liver could be excluded. Perfusate lactate concentrations remained constant during the period when the elevated rate of gluconeogenesis was observed with diabetic liver. Addition of insulin as a bolus $(750 \mathrm{mU})$ and continuous infusion $(12.5 \mathrm{mU} / \mathrm{min})$ to the perfusion medium of diabetic livers resulted in constant perfusate levels of glucose, urea and $\alpha$-amino nitrogen indicating a suppression of the catabolic processes present in the fasted, diabetic liver. The rate of ketogenesis was also slowed by insulin to about half the rate prior to addition of the hormone. These data indicate that insulin has an immediate anti-catabolic effect in the perfused, diabetic liver.

Key words: Diabetes, liver, perfusion, insulin, gluconeogenesis, ureogenesis, ketogenesis, $\alpha$-amino nitrogen, triglyceride.

The demonstration of a direct effect of insulin on the isolated perfused rat liver has shown that the hormone decreases glucose [1,2], urea [1, 3] and amino acid production [3]. Recently, Mortimore and Mondon [4] have reported that insulin had an in-

Visiting Professor of Biochemistry. Permanent Address: Department of Biochemistry, University of Litoral, Santa Fe, Argentina hibitory effect on the release of valine from protein but failed to show any influence of the hormone on its incorporation into liver protein in the isolated perfused rat liver. One might expect that the diabetic liver, with its high rates of catabolism $[5,6]$, might be particularly responsive to insulin addition in the isolated liver perfusion system.

Insulin treatment in vivo as short as $0.5 \mathrm{~h}$ before isolating the liver from diabetic rats has been shown to reverse metabolic alterations in the isolated, perfused diabetic liver [6]. Although insulin addition to the medium perfusing the alloxan diabetic liver has been shown to decrease amino acid production [7], there is no consistent view on the effect of insulin in vitro on urea and glucose production of the isolated, diabetic rat liver [7-11].

In the present study, we have investigated the addition of insulin in vitro to the perfused, fasted diabetic rat liver in order to resolve these problems.

\section{Materials and Methods}

\section{Materials}

Male albino rats of the Sprague-Dawley strain were obtained from ARS Sprague-Dawley, Madison, Wisconsin. Bovine fraction $\mathrm{V}$ albumin was purchased from Miles Laboratories, Inc., Elkhart, Indiana and purified as described below. Outdated, packed human erythrocytes were supplied by the Milwaukee Blood Center, Milwaukee, Wisconsin, and were used within five days of their expiration. Alloxan monohydrate was obtained from Nutritional Biochemicals, Cleveland, Ohio. Lente insulin (Eli Lilly, Indianapolis, Indiana) was utilized for maintenance of diabetic rats. Porcine insulin $(0.002 \%$ glucagon) used in the perfusion studies was a gift 
from Dr. Mary A. Root, Indianapolis, Indiana (Lot No.615-D63-10). The enzyme and co-factors necessary for the analysis of perfusate samples were obtained either from Boehringer Mannheim Corporation, New York, New York, or Sigma, St. Louis, Missouri. All other chemicals were of reagent grade.

\section{Alloxan Diabetes}

Fed, male rats, weighing approximately $170 \mathrm{~g}$, were lightly anaesthetized with ether and the femoral vein was exposed. Alloxan monohydrate $(60 \mathrm{mg} / \mathrm{kg})$ in $9 \mathrm{~g} / 1 \mathrm{NaCl}$ was injected as a bolus IV, followed by an IP injection of $5 \mathrm{ml}$ of $9 \mathrm{~g} / \mathrm{l} \mathrm{NaCl}$. Controls received only the sodium chloride in amounts similar to alloxan-treated rats. Approximately $36 \mathrm{~h}$ later, $6 \mathrm{U}$ of Lente insulin SC were given and this continued daily. Alloxan diabetic rats were maintained on insulin replacement therapy for at least 2 weeks, at which time they reached a weight (approximately $250 \mathrm{~g})$ similar to the control rats. The last insulin injection was given $48-54 \mathrm{~h}$ before the livers were to be perfused. Twenty-four to $30 \mathrm{~h}$ before the perfusion time, diabetic and normal rats were placed in metabolism cages without food. All diabetic rats exhibited polyuria, glucosuria (Diastix ${ }^{\circledR}$, Ames Company, Elkhart, Indiana) and in most cases ketonuria (Acetest ${ }^{\circledR}$, Ames Company, Elkhart, Indiana).

\section{Liver Perfusion}

The in situ isolated rat liver perfusion as described by Hems et al. [12] was used. The perfusion medium $(100 \mathrm{ml})$ consisted of: washed, outdated human erythrocytes to give a final hemoglobin concentration [13] of approximately $4.5 \mathrm{~g} ; 2 \mathrm{~g}$ of dialyzed, lypholized bovine serum albumin and Krebs-Henseleit [14] bicarbonate buffer-pH 7.4, previously gassed with $95 \% \quad \mathrm{O}_{2}: 5 \% \quad \mathrm{CO}_{2}$. The perfusion medium was prepared without added glucose to enable the detection of small changes in perfusate glucose, since no exogenous gluconeogenesis substrate such as alanine was added.

Criteria used in determining success of perfusion were liver color, flow rates $(1.2 \mathrm{ml} / \mathrm{g}$ wet $\mathrm{wt} / \mathrm{min}$ with 15 to $20 \mathrm{~cm} \mathrm{H}_{2} \mathrm{O}$ hydrostatic pressure) and wet $w t /$ dry wt ratio (3.5 to 3.75 ). The wet wt/dry wt ratio was determined by drying a weighed piece of liver at $125^{\circ} \mathrm{C}$ for at least $6 \mathrm{~h}$ and reweighing. The values obtained were in good agreement with those reported by Hems et al. [12].

Both normal and diabetic livers were perfused for a $30 \mathrm{~min}$ equilibration time before perfusate and/or tissue samples were obtained for analysis. Perfusate samples were then obtained from the re- servoir at $5 \mathrm{~min}$ intervals for an additional $60 \mathrm{~min}$ and protein-free filtrates were prepared with perchloric acid. In some experiments a liver biopsy $(\sim 200 \mathrm{mg})$ was taken after $30 \mathrm{~min}$ equilibration and immediately frozen with Wollenberger clamps [15], precooled with liquid $\mathrm{N}_{2}$. All tissue samples were powdered with a percussion mortar and stored at liquid $\mathrm{N}_{2}$ temperature until the glycogen and triglyceride analyses were performed.

The effect of insulin on diabetic liver metabolism was studied by adding $750 \mathrm{mU}$ of the hormone in $1 \mathrm{ml}$ of $2 \mathrm{~g} / 100 \mathrm{ml}$ albumin after $30 \mathrm{~min}$ of the experimental period and an infusion of $12.5 \mathrm{mU} / \mathrm{min}$ for $30 \mathrm{~min}$ was continued until the end of the perfusion. The normal and diabetic livers without insulin received the same amounts of albumin alone.

\section{Determination of Perfusate and Liver Constituents}

Glucose [16], lactate [17], acetoacetate [18], 3-hydroxybutyrate [19], and urea [20] in protein-free filtrates of perfusion medium were determined by enzymatic methods. Perfusate $\alpha$-amino $\mathrm{N}$ was analyzed by the ninhydrin procedure of Rosen [21]. Glycogen and triglyceride in frozen powder of liver samples were determined as described by Huijing [22] (results expressed as glycogen-glucose) and Laurell [23], respectively. All perfusate and liver constituents were expressed as $\mu \mathrm{mol} / \mathrm{g}$ wet liver. Total ketone bodies in the perfusate are the sum of acetoacetate and 3-hydroxybutyrate. Rates of metabolite production were calculated for the 30-60 $\min$ and 60-90 min periods using linear least squares regression analysis. The correlation coefficient was always greater than 0.9 for these fits. Upon addition of insulin to the perfusate of diabetic livers, rates for gluconeogenesis and ureogenesis could not be calculated as the hormone completely suppressed these processes. Significance of differences between experimental groups of perfused livers were tested by Student's t-test.

\section{Results}

The rates of gluconeogenesis, ureogenesis and ketogenesis over two 30 min perfusion intervals of perfused livers from normal rats fasted for $24 \mathrm{~h}$ were determined (Table 1). The rates of ureogenesis and ketogenesis were similar over both intervals, while the production of glucose by the liver from normal rats was approximately twice as high $(\mathrm{P}<0.02)$ during the first interval $(30-60 \mathrm{~min})$ than the second $(60-90 \mathrm{~min})$. The difference in the rate of glucose production between the two perfusion in- 
tervals can be accounted for by the decrease in perfusion medium lactate concentration from 1.2 to $0.6 \mathrm{mmol} / 1$ which occurred during the period 30 to $60 \mathrm{~min}$. This rate of lactate uptake $(0.25 \mu \mathrm{mol} / \mathrm{g}$ wet liver/min) during the period of 30 to $60 \mathrm{~min}$ could account for most of the difference in the rates of gluconeogenesis observed, if one assumes stoichometric conversion of lactate to glucose. Liver glycogs:n content were extremely low in perfused livers from normal, fasted rats after $30 \mathrm{~min}$ of perfusion (approximately $1 \mu \mathrm{mol}$ glycogen-glucose/g wet liver). Thus, the possible contribution of liver glycogen to the observed rate of gluconeogenesis was negligible. During the perfusion interval 60-90 min, medium lactate content remained constant at $0.4 \mathrm{mmol} / \mathrm{l}$ with perfused livers from normal, fasted rats. The production of $\alpha$-amino $\mathrm{N}$ (Table 2) and rates of ureogenesis (Table 1), the values of which were constant during both intervals, indicated that endogenous liver protein breakdown provided the major share of the carbon necessary for the rate of gluconeogenesis observed, especially when perfusate lactate remained constant during 60-90 min.

The goal of the present study was to investigate if the addition of insulin to the perfusion medium of perfused diabetic livers would alter the metabolic aberrations observed with such livers. Perfusion of livers from fasted, diabetic rats in the absence or présence of insulin in vitro, under conditions exactly similar to those for normal rat livers except for the added variable of insulin infusion (60-90 min), was performed. During the perfusion interval (30$60 \mathrm{~min}$ ) before insulin addition to the medium was made, the rates of ureogenesis and ketogenesis of diabetic liver were 2.5 and 4.5 times higher $(\mathrm{P}<0.01)$ respectively than the normal liver (Table 1). The almost four fold higher rate of $\alpha$-amino $\mathrm{N}$ production with perfused diabetic livers when compared to normal $(\mathrm{P}<0.01)$ was also indicative of high rates of liver protein catabolism (Table 2). The perfusion medium lactate had already reached a constant low value of $0.5 \mathrm{mmol} / \mathrm{l}$ with diabetic liver after $30 \mathrm{~min}$ of perfusion, similar to the value reached with normal livers after $60 \mathrm{~min}$. Consequently, the observed rate of glucose production was due directly to endogenous liver protein catabolism. Thus, if one corrects for the probable contribution of lactate uptake in the rate of gluconeogenesis observed with the normal fasted liver, the rate found with diabetic liver is approximately 1.5 times higher (Table 1).

The rate of gluconeogenesis observed with diabetic livers over the perfusion interval $30-90 \mathrm{~min}$ $(0.37 \mu \mathrm{mol} / \mathrm{g} / \mathrm{min})$ indicated that the increased rates indicated above for the interval $30-60 \mathrm{~min}$
Table 1. Rates of gluconeogenesis, ureogenesis and ketogenesis with perfused livers from normal and diabetic rats

\begin{tabular}{|c|c|c|c|c|}
\hline \multirow[b]{2}{*}{ Group } & \multicolumn{2}{|c|}{$\begin{array}{l}\text { Insulin addition } \\
\text { to perfusion medium* }\end{array}$} & \multicolumn{2}{|c|}{ Perfusion interval } \\
\hline & $\begin{array}{l}30 \text { to } \\
60 \mathrm{~min}\end{array}$ & $\begin{array}{l}60 \text { to } \\
90 \mathrm{~min}\end{array}$ & 30 to $60 \mathrm{~min}$ & 60 to $90 \mathrm{~min}$ \\
\hline & & & \multicolumn{2}{|c|}{$\begin{array}{l}\text { Gluconeogenesis } \\
\text { ( } \mu \mathrm{mol} / \mathrm{g} \text { wet liver } / \mathrm{min})\end{array}$} \\
\hline Normal (7) & - & - & $0.33 \pm 0.06$ & $0.14 \pm 0.02$ \\
\hline \multirow[t]{2}{*}{ Diabetic (4) } & - & + & $0.31 \pm 0.07$ & (See Fig. 1) \\
\hline & & & \multicolumn{2}{|c|}{$\begin{array}{l}\text { Ureogenesis } \\
(\mu \mathrm{mol} / \mathrm{g} \text { wet liver } / \mathrm{min})\end{array}$} \\
\hline Normal (7) & - & - & $0.21 \pm 0.05$ & $0.21 \pm 0.06$ \\
\hline \multirow[t]{2}{*}{ Diabetic (4) } & - & + & $0.52 \pm 0.17$ & (See Fig. 1) \\
\hline & & & \multicolumn{2}{|c|}{$\begin{array}{l}\text { Ketogenesis } \\
(\mu \mathrm{mol} / \mathrm{g} \text { wet liver } / \mathrm{min})\end{array}$} \\
\hline Normal (7) & - & - & $0.12 \pm 0.03$ & $0.15 \pm 0.03$ \\
\hline Diabetic (4) & - & + & $0.54 \pm 0.02$ & $0.27 \pm 0.07$ \\
\hline
\end{tabular}

After a 30 min equilibration time, perfusate samples were obtained and concentration of metabolites measured as described in the text. Rates of gluconeogenesis, ureogenesis, and ketogenesis are given as the mean \pm SEM for the number of perfusions which are listed as the figure in the parenthesis. *Addition of the $750 \mathrm{mU}$ insulin was made at $60 \mathrm{~min}$ and an infusion of $12.5 \mathrm{mU} /$ min was continued over the next $30 \mathrm{~min}$ with the diabetic liver

Table 2. Production of $\alpha$-amino $\mathrm{N}$ with perfused livers from normal and diabetic rats

\begin{tabular}{|c|c|c|c|c|}
\hline \multirow[b]{2}{*}{ Group } & \multicolumn{2}{|c|}{$\begin{array}{l}\text { Insulin addition } \\
\text { to perfusion medium* }\end{array}$} & \multicolumn{2}{|c|}{$\begin{array}{l}\text { Release of } \alpha \text {-amino } \mathrm{N} \\
\text { Perfusion interval }\end{array}$} \\
\hline & $\begin{array}{l}30 \text { to } \\
60 \mathrm{~min}\end{array}$ & $\begin{array}{l}60 \text { to } \\
90 \mathrm{~min}\end{array}$ & $\begin{array}{l}30 \text { to } 60 \mathrm{~min} \\
\mu \mathrm{mol} / \mathrm{g} \text { wet } \mathrm{w}\end{array}$ & $\begin{array}{l}60 \text { to } 90 \mathrm{~min} \\
\text { eight }\end{array}$ \\
\hline Normal (6) & - & - & $2.1 \pm 0.9$ & $2.5 \pm 2.1$ \\
\hline Diabetic (4) & - & + & $7.9 \pm 1.4$ & $0.0 \pm 1.1$ \\
\hline
\end{tabular}

Perfusate $\alpha$-amino $\mathrm{N}$ was determined as described in the Materials and Methods. Details of treatment of rats and perfusion conditions are given in the text. Values given are the mean \pm SEM for the number of perfusions which is given in parenthesis. *Addition of $750 \mathrm{mU}$ insulin was made at $60 \mathrm{~min}$ and an infusion of $12.5 \mathrm{mU} / \mathrm{min}$ was continued over the next $30 \mathrm{~min}$ with the diabetic liver

$(0.31 \mu \mathrm{mol} / \mathrm{g} / \mathrm{min})$ were maintained and linear throughout the experiment. Thus, the effect of insulin addition to the medium at $60 \mathrm{~min}$ of perfusion time was studied over the next $30 \mathrm{~min}$. The results of insulin addition at 60 min continuous infusion over the next $30 \mathrm{~min}$ interval with the same group of diabetic rats and under exactly the same perfusion conditions as in the absence of insulin are summarized in Figure 1 and Table 1. There was an immediate fall in the accumulation of medium glucose and urea upon addition of insulin to the perfusion 


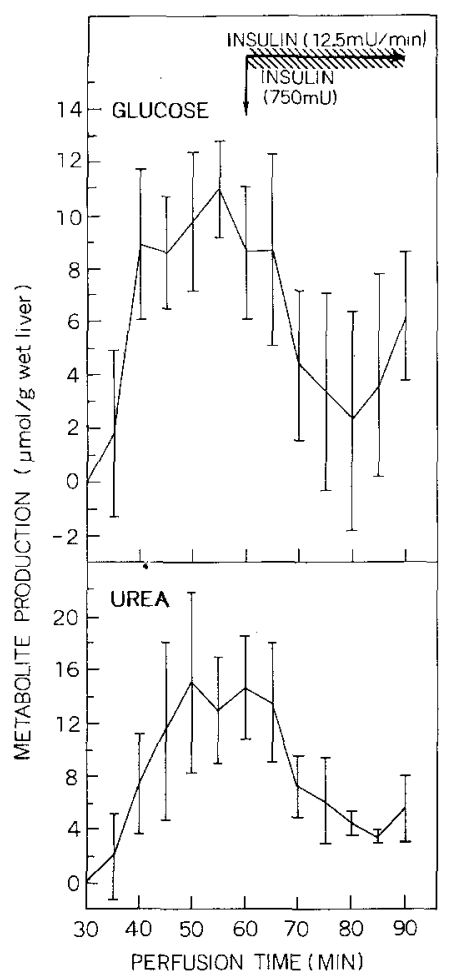

Fig. 1. Effect of insulin infusion $(750 \mathrm{mU}$ at $60 \mathrm{~min}+12.5 \mathrm{mU} /$ $\mathrm{min}$ for the period $60-90 \mathrm{~min}$ ), on the production of glucose and urea in perfused livers from fasted, diabetic rats $(24 \mathrm{~h})$. Perfusate metabolites were determined as described in the Materials and Methods. Values represent mean \pm SEM

medium (Fig. 1). The rate of ketogenesis with perfused diabetic liver after addition of insulin was only one-half the value of that without the hormone $(\mathrm{P}<0.01$; Table 1$)$. Determination of $\alpha$-amino $\mathrm{N}$ levels in the perfusate further indicated that addition of insulin to the perfusion medium completely blocked endogenous liver protein breakdown $(\mathrm{P}<0.01$; Table 2$)$. The approximately 2 fold higher level of triglyceride in the diabetic liver $(36.6 \mu \mathrm{mol} /$ triglyceride-glycerol/g wet liver), when compared to the value for normal $(18.7 \mu \mathrm{mol} / \mathrm{g})$ at $30 \mathrm{~min}$ of perfusion, correlates well with the high rates of ketogenesis observed with the perfused diabetic liver (Table 1).

\section{Discussion}

In the present study, the rates of gluconeogenesis, ureogenesis and ketogenesis were elevated severalfold in isolated fasted diabetic liver over those found with the normal fasted liver. The acute diabetic state was produced by giving the last insulin injection 48-54 $\mathrm{h}$ before liver perfusion and superimposing a fast during the last $24 \mathrm{~h}$. In most reported studies the perfusion of livers from diabetic rats in the fed state have allowed only the measurement of glucose balance, since significant shifts in liver glycogen content occur during the interval of perfusion $[7,9,11$, 24]. The use of $\left[{ }^{14} \mathrm{C}\right]$-lactate as gluconeogenic substrate in the experiments conducted by Exton et al. [6] with isolated livers from fed alloxan-diabetic rats led to the conclusion that the rate of gluconeogenesis with these livers was twice that found with livers from fed normal rats.

The relative contribution of counter-regulatory hormones such as glucagon $[25,26]$ or glucocorticoids [27] in the observed elevated rates of gluconeogenesis, ureogenesis, ketogenesis, and amino acid production by the isolated perfused diabetic liver was not ascertained in the present study. However, addition of insulin to perfusion medium resulted in an immediate reversal of the catabolic processes just mentioned. The cessation of amino acid release and urea production by isolated diabetic liver was observed upon insulin addition to the perfused liver from diabetic rats.

Although stimulation of protein synthesis by insulin could explain our observations, Mortimore and Mondon [4] have shown that a major role of insulin in protein turnover is in the control of proteolysis. The simultaneous decrease in the rate of gluconeogenesis and protein catabolism occurring with the isolated perfused diabetic liver in the presence of insulin supports the conclusion that liver protein breakdown during perfusion of the diabetic liver provides the carbon source for gluconeogenesis under these conditions.

In any case, addition of insulin to the perfusate reversed the increased catabolism observed with the perfused livers from fasted diabetic rats in the present study. Although insulin action on liver, especially its interaction with glucagon on the organ, was postulated to involve cyclic AMP almost ten years ago $[25,26]$, the exact locus of this effect remains controversial. Furthermore, the mechanism by which insulin exerts its acute anticatabolic effect remains to be elucidated.

Acknowledgement. This work was supported by U.S. Public Health Service General Research Support and TOPS Club, Inc., Obesity and Metabolic Research Program, Milwaukee, Wisconsin.

\section{References}

1. Mortimore, G. E.: Effect of insulin on release of glucose and urea by isolated rat liver. Am. J. Physiol. 204, 699-704 (1963) 
2. Mortimore, G. E., King, E., Jr., Mondon, C. E., Glinsmann, W.H.: Effects of insulin on net carbohydrate alterations in perfused rat liver. Am. J. Physiol. 212, 179-183 (1967)

3. Mondon, C. E., Mortimore, G. E.: Effects of insulin on amino acid release and urea formation in perfused rat liver. Am. J. Physiol. 212, 173-178 (1967)

4. Mortimore, G. E., Mondon, D.E.: Inhibition by insulin of valine turnover in liver. Evidence for a general control of proteolysis. J. Biol. Chem. 245, 2375-2383 (1970)

5. Heimberg, M., Dunkerley, A., Brown, T.O.: Hepatic lipid metabolism in experimental diabetes. I. Release and uptake of triglycerides by perfused livers from normal and alloxandiabetic rats. Biochim. Biophys. Acta 125, 252-264 (1966)

6. Exton, J.H., Harper, S.C., Tucker, A. L., Ho, R.-J.: Effects of insulin on gluconeogenesis and cyclic AMP levels in perfused livers from diabetic rats. Biochim. Biophys. Acta 329, 23-40 (1973)

7. Söling, H. D., Kneer, P., Drägert, W., Creutzfeldt, W.: Die Wirkung von Insulin auf den Stoffwechsel der isolierten perfundierten Leber normaler und alloxandiabetischer Ratten. II. Stoffwechseländerungen unter dem Einfluß intraportaler Insulininfusionen. Diabetologia 2, 32-44 (1966)

8. Miller, L. L.: Some direct actions of insulin, glucagon, and hydrocortisone on the isolated perfused rat liver. Recent Prog. Horm. Res. 17, 539-564 (1961)

9. Haft, D. E., Miller, L. L.: Alloxan diabetes and demonstrated direct action of insulin on metabolim of isolated perfused rat liver. Am. J. Physiol. 192, 33-42 (1958)

10. Boden, G., Willms, B.: Einfluß von Insulin auf Kohlenhydrat und Fettstoffwechsel der perfundierten Leber bei normalen und Alloxan-diabetischen Ratten. Klin. Wochenschr. 44, 579-583 (1966)

11. Haft, D. E.: Studies of the metabolism of isolated livers of normal and alloxan-diabetic rats perfused with insulin. Diabetes 17, 244-250 (1968)

12. Hems, R., Ross, B.D., Berry, M.N., Krebs, H.A.: Gluconeogenesis in the perfused rat liver. Biochem. J. 101, 284-292 (1966)

13. Eilers, R. J.: Notification of final adoption of an international method and standard solution for hemoglobinometry specification for preparation of standard solution. Am. J. Clin. Pathol. 47, 212-214 (1967)

14. Krebs, H. A., Henseleit, K.: Untersuchungen über die Harnstoffbildung im Tierkörper. Hoppe Seylers Z. Physiol. Chem. 210, 33-66 (1932)

15. Wollenberger, A., Ristau, O., Schoffa, G.: Eine einfache Technik der extrem schnellen Abkühlung größerer Gewebestücke. Pfluegers Arch. 270, 399-412 (1960)
16. Lloyd, G.B., Whelan, W. J.: An improved method for enzymic determination of glucose in the presence of maltose. Anal. Biochem. 30, 467-469 (1969)

17. Hohorst, H. J.: L- $(+)$-lactate: Determination with lactic dehydrogenase and DPN. In: H.U. Bergmeyer (ed.): Methods of Enzymatic Analysis, pp. 266-270. New York and London: Academic Press 1965

18. Mellanby, J., Williamson, D.H.: Acetoacetate. In: H.U Bergmeyer (ed.): Methods of Enzymatic Analysis, pp. 454-458. New York and London: Academic Press 1965

19. Williamson, D. H., Mellanby, J.: D- $(-)$ - $\beta$-hydroxybutyrate. In: H. U. Bergmeyer (ed.): Methods of Enzymatic Analysis, pp. 459-461. New York and London: Academic Press 1965

20. Kaplan, A.P.: Urea nitrogen and urinary ammonia. In: S. Meites (ed.): Standard Methods of Clinical Chemistry, pp. 245-256. New York: Academic Press 1965

21. Rosen, H.: A modified ninhydrin colorimetric analysis for amino acids. Arch. Biochem. Biophys. 67, 10-15 (1967)

22. Huijing, F.: A rapid enzymatic method for glycogen estimation in very small tissue samples. Clin. Chim. Acta 30, $567-572(1970)$

23. Laurell, S.: A method for routine determination of plasma triglycerides. Scand. J. Clin. Lab. Invest. 18, 668-672 (1966)

24. Woodside, W.F., Heimberg, M.: Effects of anti-insulin serum, insulin, and glucose on output of triglycerides and on ketogenesis by the perfused rat liver. J. Biol. Chem. 251, 13-23 (1976)

25. Jefferson, L.S., Exton, J.H., Butcher, R.W., Sutherland, E.W., Park, C.R.: Role of adenosine 3', 5'-monophosphate in the effects of insulin and anti-insulin serum on liver metabolism. J. Biol. Chem. 243, 1031-1038 (1968)

26. Menahan, L. A., Wieland, O.: Interaction of glucagon and insulin on the metabolism of perfused livers from fasted rats. Eur. J. Biochem. 9, 55-62 (1969)

27. Exton, J.H., Harper, S. C., Tucker, A. L., Flagg, J.L., Park, C. R.: Effects of adrenalectomy and glucocorticoid replacement on gluconeogenesis in perfused livers from diabetic rats. Biochim. Biophys. Acta 329, 41-57 (1973)

Received: April 25, 1977, and in revised form:

July 19, 1977

Dr. L. A. Menahan

Department of Pharmacology

Medical College of Wisconsin

561 North 15 Street

Milwaukee, WI 53233

USA 